\title{
Mental illness as a contributor to intentional self inflicted suicidal burn injury
}

\author{
Nahid Shahana ${ }^{1}$, Tanvir Chowdhury Turin ${ }^{2}$, Nahid Rumana ${ }^{3}$. AFM Mohibur Rahman ${ }^{6}$, Major \\ Sharmin Hossain, ,Saifun Nahar ${ }^{4}$ \\ ${ }^{1}$ Associate Professor, Department of Anatomy, Bangladesh Medical College, Dhaka, Bangladesh, ${ }^{2}$ Post doctoral \\ Researcher, Department of Health Science, Shiga University of Medical Science, Shiga, Japan, ${ }^{3}$ Post doctoral \\ Researcher, Department of Health Science, Shiga University of Medical Science, Shiga, Japan, ${ }^{4}$ Associate \\ Professor, Department of Anatomy, Holy Family Medical College, Dhaka, Bangladesh, ${ }^{5}$ Instractor Anatomy, Armed \\ Forces Medical College, Dhaka, Bangladesh, ${ }^{6}$ Professor (C.C), Department of Pharmacology, Holy Family Medical \\ College, Dhaka, Bangladesh.
}

\begin{abstract}
Self inflicted burn injuries are infrequent but very much distressing. It is a result of social, environmental and individual factors. Self-inflicted burns are usually an outcome of mental illness, and acute phase schizophrenia is considered as one of the major precipitating factor. The aim of this study was to find out and summarize the existing findings of different studies regarding mental illness as a contributor to suicide and/or intentional self inflicted injury. Literature review of some of previous studies from journals and databases were performed. Electronic database (Medline) was searched and twenty four studies were found to be related to the present objective. Among the 10 studies were randomly selected. The studies ranged from 1991-2005. The literature review suggested that quite a good number of incidents of self inflicted burns are committed by people having mental disorder. Among the self inflicted burns patient, the males were seen to be higher in number in most of the studies' provided information. The range of the age was 14 to 90 years collectively. And among them a significant number of people are suffering from schizophrenia. Depression, substance abuse, personality disorder, psychosis were among the other mental health illness contributing to the incidence of self inflicting burns injury. Specific attention should be given in this aspect as for the vulnerable group depends heavily on their care givers. Since a number of inter-related risk factors may be involved, solving the problem from a new perspective-the safety promotion perspective should be initiated.
\end{abstract}

Key Words: $\quad$ Mental illness, Schizophrenia, self inflicted injury, burn.

\section{Introduction}

There are a wide range of psychological states that need medical intervention in forms of medicine or counseling. Theses are mental illness. Mental illnesses are distinguished by anomaly in intellectual ability, emotion or frame of mind, social interactions, performing rational activities, etc. Moreover, the manifestations of mental disorders vary with age, gender, race, and culture ${ }^{1}$. Among the mental illnesses, schizophrenia is chronic and disabling disease. Rates of schizophrenia differ from country to country ${ }^{2-4}$. Schizophrenia ranks among the top 10 causes of disability in developed countries worldwide ${ }^{5}$. It has been reported that developing countries had lower prevalence rates than the developing world ${ }^{2-4}$. The risk of suicide is serious in people with schizophrenia ${ }^{6}$. Most people with schizophrenia, however, are not violent toward others but are withdrawn, introvert, self centered and prefer to be left alone. Stress, drug and /or alcohol abuse, social abuse increases the risk of violence in people with schizophrenia, predominantly if the illness is untreated ${ }^{7-8}$. People with schizophrenia frequently suffer terrible symptoms such as hearing voices which in reality is not heard by other people or believing that other people are able to read their minds and are controlling their thoughts, or people are planning to cause harm to them. These symptoms make them frightened and they stay away from the others and live a withdrawn life from the surroundings. They become very much reclusive and self centered in their daily life.

Self injury is the act of inflicting physical harm serious enough to cause tissue damage to one's own body. Usually self injurer people use physical self-injury as a manner of dealing with stressful situation they face in their life. They take it as a way of reducing the unbearable tension or pressure they under go. It causes physiological and psychological tension to reduce rapidly. It brings down the pressure to a bearable and manageable level from the initial status. A self-injurer can come from any walk of life of our society. He or she can be from any economic background, any educational background or any socio-demographic status, from any 
J. Dhaka National Med. Coll. Hos. 2011; 18 (01): 49-57 country in the world. It cannot be deemed as fact that only unsuccessful people commits self injures activity, some people who self-injure manage to function efficiently in challenging occupation. Some times very successful people of their work commits to self inflicting injury behavior. Normally there are some signs seen in the behavior of the self injurer. But most of the times they are so mild that it can not be readily identified. The close associations of the self injurer may have some clue about these changes rather than the outsiders. Warning signs that someone is causing self inflected injury to themselves include: low confidence, difficulty handling emotions, unexplained frequent injury signs, scars including cuts and burns, hiding attitude relating to otherwise normally visible parts of body, personal relationship problems, and poor performance in functioning at job, school or home. Suicidal attempt and complete suicide is a serious public health problem ${ }^{9}$. According to the Surgeon General's Call to Action to Prevent Suicide ${ }^{10}$ hospitalizations for self-inflicted injuries also exceed those for assault-related injuries in the US. Death from suicide represents an almost excruciating catastrophe for millions who survive the loss of someone close to them, thus putting themselves at risk for suicide. Self-injury primarily is used as a coping mechanism. General forms of self-injury include, but are not limited to: cutting, burning, hitting, biting, etc. Self-Injury is not in itself a disease condition; it normally co-exists with other mainly psychological conditions. Self-injury may also be present in patients diagnosed with mood disorders such as depression, bipolar disorder, manic depression, eating disorders, anxiety disorders, panic attacks, Post-Traumatic Stress Disorder. There are many different triggers which may cause a person to self-harm him or herself. Some people may do it for the pain, either because they just want to experience something, or some will do the act simply to punish themselves. To some people causing self inflected injury is otherwise symbolic somehow of getting rid of the overwhelming stress and pain they are undergoing. The coverage of the problem is searched in order to asses the major risk factor of the mental disorder. So that the initiative of taking a more cautious approach towards this vulnerable group can be thought of.

\section{Methodology}

Literature reviews on the epidemiology of self inflicted burns were undertaken. Electronic database (MEDLINE) was searched. The search terms used were self inflict burn, mental disorder, schizophrenia, epidemiology, self-harm. Using the search words the search was preformed using the facility of PubMed which is a service of the "National Library of Medicine" (NLM) that includes over 15 million citations from MEDLINE. PubMed is available via the National Center for Biotechnology Information (NCBI) Entrez retrieval system, which was developed by the NCBI at the NLM, located at the National Institutes of Health (NIH). This is a free web based search program which includes links to articles and other related resources. Seventy six matches were shown after the search with the key word "self inflicted burn". The abstracts available online were gone through and Twenty four of them were found to be related to the present objective. Among the 10 studies were randomly selected. Reference copies for these ten studies were searched / requested in the authors' university library. Nine of them were available, which were used for this review purpose. The list of the studies are provided in the Appendices-a.

\section{Result}

The 9 studies reviewed all were retrospective in nature. Studies focused to a time frame ranging from 2 years to 20 years retrospective data. The number of total burn incident is 15531. The percentage of self inflicted burns cases ranged from $0.67 \%$ to $5.7 \%$ among the studies.

Table 1 show the study country, duration and incidence and age, sex distribution of the burn injury. Among the self inflicted burns patient, the males were seen to be higher in number in most of the studies' provided information. The average age of the patients ranged from 26.9 to 53.5 years of age. The range of the age was 14 to 90 years collectively. Maximum length range was observed for the Greece study with the range of 18 to 90 years. The average age was highest in the Greece population (53.5 years) and lowest among the Iran population (26.9 years).

Table 2 summarizes the duration of hospital stay, total burned surface area (TBSA) and the mortality of the self inflicted burning patients according to the studies reviewed. Death due burn injury was a major outcome of the self inflicted burns patients. Significant numbers of mortality was observed in most of the studies. Duration of the hospital stays varied among the studies, ranging from on an average of 16 days to as high as 59 days. Average TBSA varied from $24 \%$ to $67.3 \%$ among the studies. Four of the studies also find out the place of the incidence of self burning. Majority of the 
J. Dhaka National Med. Coll. Hos. 2011; 18 (01): 49-57 patients inflicted burns injury towards them at home. Among the material methods used for the self inflicted injuries gasoline and flame were found to be the most common one. Most of the studies have reported their use.

Table 3 summarizes the Psychiatric history among the patients according to the studies reviewed. It also shows the history of previous triggers among the cases of self inflicted burns. Schizophrenia is identified to be a major type of mental illness in most of the studies. Depression is also another important mental health illness among the patients. Substance abuse, personality disorder, psychosis etc were among the mental health illness contributing to the incidence of self inflicting burns injury.

\section{Discussions}

In the contrary to the common belief, people with schizophrenia are more likely to cause harm to them rather than be violent toward others. Violence is not a symptom of schizophrenia. Most people with schizophrenia are self centered, introverted, have a tendency of to be withdrawn from the surroundings and prefer to be left alone. Drug or alcohol abuse increases the risk of violence in people with schizophrenia, and particularly if the illness is untreated. But if even violence does occur, it is most frequently targeted at close surroundings as family members and friends, and more often takes place at home and some more when they feel threatened. Substance abuse like drugs abuse and /or alcohol abuse notably raises the risk of violence in people with schizophrenia, but as well also in the cases with people who does not suffer from any mental illness. Apart from Schizophrenia self-harm behavior can be an indicator for several other psychiatric diseases also: personality disorders as borderline personality disorder, bipolar disorder as manic depression, major depression, anxiety disorders, etc

The percentage of self-inflicted burns among patients admitted to burn units ranges widely with substantial inconsistency all over the world and some differences exists between the various countries, regarding the etiology, risk groups, patterns of selfinflicted burns ${ }^{11-17}$. Self-inflicted burns are usually an outcome of psychiatric disorders, and an acute phase of depression or schizophrenia is the main precipitating factor in the developed countries. Self inflicted burns attempts usually are most commonly associated with pre-existing psychiatric disorders and various predisposing factors. Previously identified risk factors for self inflicting injury behaviors have been observed in the setting of self inflicted burns ${ }^{18-19}$. These include being of the male sex, single marital status, active psychiatric illness and substance abuse.

Deliberate self inflicted burns correspond to a small but consistent percentage of hospital admissions, morbidity and mortality around the world. A numbers of variations have been observed between those patients who attempted suicide and those patients who deliberately burnt themselves for other reasons ${ }^{20}$. Self inflicted burns injuries usually are distressing and produce a significant mortality and morbidity because they often may require long term hospitalization and long term care from the care givers and may result in long term disability with serious physical as well as psychological after effects. Especially the developing society these types of visible disability will cause the victim to have a very poor social life and have every chance to cause the mental illness status to become worse than before from the society reaction. The lack of constructive surgery treatment in the developing world set up it makes difficult for the victims to be rehabilitated in the common flow of the society. They more or less become stigmatized making their life more difficult.

Self inflicted burns have been considered as a serious mental health problem through out the world and especially among the economically developing nations. Though it is an uncommon method of self injury but it incurs quite a sizable cost to hospital services, health care services as well as on the economy on the victims' family. These patients usually require full resuscitation on a specialized burn unit, large amount of intravenous fluids, antibiotics, and other drugs. This is normally very expensive cost in relation to the health care providers. They also may require many surgical procedures, dressing changes, patient's personal need care which place huge human demands on medical nursing in over all aspect.

Self-inflicted burns are generally an outcome as well as indicator and symptom of psychiatric disorders, and an acute phase of schizophrenia or depression mostly acts as the main precipitating factor. Most authors report that previous history of psychiatric illness is an important element in predisposition to self burning 21-24. Among the studies we have reviewed, except Rastegar \& Alaghehbandan (2003) ${ }^{25}$, all other studies showed Schizophrenia as a previous history among cases ranging from as low as $6 \%$ (Pham et al., $2003{ }^{26}$ ) to as high as $73.8 \%$ (Garcia et al., $1994^{27}$ ). Rastegar \& 
J. Dhaka National Med. Coll. Hos. 2011; 18 (01): 49-57 Alaghehbandan (2003) ${ }^{25}$ of Iran showed Depression $(47.7 \%)$ as the prime previous history of mental disorder. Research reported that self-inflicted burns constitute a predominantly psychotic act ${ }^{28}$. And there is often a history of childhood arson and multiple previous attempts at suicide by burning. The studies we have reviewed showed suicidal attempt present as a previous history among cases ranging from as low as $17.4 \%$ by Tasti et al. ${ }^{29}$ to as high as $63.6 \%$ by Erzurum \& Varcellotti ${ }^{13}$.

The mortality rate in the group of self inflicting injurers is reported $25 \%$ (Jacobsen et al.) ${ }^{28}$. All over the world it was observed that self inflicted burns injury incidence have different rates having a wide range of incidence and other authors report a significantly higher mortality rate than for accidental burns of comparable severity. Among the studies reviewed apart from Pham et al. ${ }^{26}$, all other studies shows a range of mortality rates among the self inflicted injury cases, ranging from as low as $17.4 \%$ ( Plamu et al.) ${ }^{30}$ to as high as $29.8 \%$ (Garcia et al.) ${ }^{27}$. The main argument is different studies surrounds the particular psychiatric diagnosis most likely to be associated with self inflicted burns. Importance of previous psychiatric illness as a precipitating factor has been reported ${ }^{21-22,31}$, where as BenMeir et al. ${ }^{32}$ found psychiatric disorders in only among half of their patients. Among the studies reviewed they have shown presence of past psychiatric problem among the majority of the cases. Pham et al. from USA found $91 \%{ }^{26}$, Erzurum \& Varcellotti from USA found $90.9 \%{ }^{13}$, Wallace \& Pegg from Australia found $69 \%{ }^{14}$, Garcia et al. from Spain found $60.3 \% \quad 27$, Rastegar \& Alaghehbandan from Iran found $43.6 \%{ }^{25}$ and Tasti et al. from Greece found $43.3 \%{ }^{29}$ of the cases to have past psychiatric problem.

Schizophrenia and depression was the most common diagnosis among the reviewed studies, which is consistent with other studies not included in the review. Our reviewed studies showed predominance of male patients, where as Davidson \& Brown ${ }^{21}$ showed no sex difference and Andreasen and Noyes ${ }^{33}$ and BenMeir et al. ${ }^{32}$ found female preponderance in their studies. In the study of Tasti et al. $84.9 \%$ of the self inflicting injury victims was single ${ }^{29}$. Cameron et al. reported $56.6 \%$ of the subjects of their study were un-employed 20 . Gasoline and flame were found to be the most common materials among the material methods used for the self inflicted injuries. Highest percentage of cases reported to have used gasoline for self inflicting injury event was in Tasti et al. $69.6 \%{ }^{29}$, followed by Pham et al. $59 \%{ }^{26}$. On the other hand Plamu et al. of Finland reported highest percentage of flame usage $82.1 \%{ }^{30}$ followed by reported $68 \%$ by Wallace \& Pegg of Australia ${ }^{14}$ as the means used for causing self inflicted burn injury. Cameron et al. of Australia also report $52 \%$ for percentage of flame usage as a manner of self inflicting injury ${ }^{20}$.

Self-inflicted burn injuries, although are uncommon but are a considerable cause of morbidity and mortality, especially among the mentally disabled persons. It also affects their care givers as well. In conclusion, we can say that patients at risk with psychiatric disorders must be recognized and treated in order to prevent self-inflicted burns. 
J. Dhaka National Med. Coll. Hos. 2011; 18 (01): 49-57

Table 1. Study country, study duration and incidence and age, sex distribution of the burn patients

\begin{tabular}{|c|c|c|c|c|c|c|c|c|c|}
\hline \multirow[t]{2}{*}{ Author } & \multirow{2}{*}{$\begin{array}{l}\text { Study } \\
\text { Year }\end{array}$} & \multirow[t]{2}{*}{ Country } & \multirow[t]{2}{*}{ Study period } & \multirow[t]{2}{*}{ TBP $\dagger$} & \multirow[t]{2}{*}{ SIBP\$ $(\%)$} & \multicolumn{2}{|c|}{ Gender } & \multicolumn{2}{|c|}{ Age of the Patient (yrs) } \\
\hline & & & & & & Male & Female & Average & Range \\
\hline Daniels SM & 1991 & USA & 1980-1989 & 2216 & $15(0.67)$ & 9 & 6 & 31.3 & $15-76$ \\
\hline Erzurum VZ & 1999 & USA & $1987-1995$ & 1135 & $11(0.97)$ & 11 & 4 & 35.7 & $17-62$ \\
\hline Wallace KL & 1999 & Australia & 1986-1996 & 2275 & $65(2.9)$ & $68 \%$ & $32 \%$ & 37.5 & $19-53$ \\
\hline Rastegar LA & 2003 & Iran & 1997-1999 & 2208 & $110(3.9)$ & 110 & 0 & 26.9 & $14-68$ \\
\hline Pham TN & 2003 & USA & $1996-2001$ & 1008 & $32(5.9)$ & $59 \%$ & $41 \%$ & $36( \pm 12.5)$ & $18-65$ \\
\hline Cameron DR & 1997 & Australia & $1990-1995$ & 1072 & $44(4.1)$ & $28(64 \%)$ & $16(36 \%)$ & 30.6 & $17-64$ \\
\hline Tasti E & 2005 & Greece & $1996-2003$ & 1435 & $53(3.69)$ & 23 & & 53.5 & $18-90$ \\
\hline Garcia SV & 1994 & Spain & $1983-1991$ & 3371 & 67 (1.98) & $48(71.6 \%)$ & $19(28.34 \%)$ & 38 & $20-60$ \\
\hline Plamu R & 2004 & Finland & 1989-1997 & 811 & $46(5.7)$ & 32 & 14 & 35.2 & --- \\
\hline
\end{tabular}

$\dagger$ TBP - Total number of burn patients.

\#SIBP - Number of self inflicted burn patients

Table 2. Hospital stay, Total Body Surface Area of burn and Death incidence among the patients

\begin{tabular}{|c|c|c|c|c|c|}
\hline \multirow[t]{2}{*}{ Author } & \multirow[t]{2}{*}{ Country } & \multicolumn{2}{|c|}{$\mathrm{TBSA}_{\dagger}(\%)$} & \multirow{2}{*}{$\begin{array}{c}\begin{array}{c}\text { Stay in } \\
\text { Hospital }\end{array} \\
\text { Days }\end{array}$} & \multirow[t]{2}{*}{ Death } \\
\hline & & Average & Range & & \\
\hline Daniels SM & USA & 67.3 & $2-96$ & 53 & 8 \\
\hline Erzurum VZ & USA & 26.1 & $4-95$ & -- & $3(27.2 \%)$ \\
\hline Wallace KL & Australia & 31.4 & $5-99$ & 40 & 14 \\
\hline Rastegar LA & Iran & 74.5 & $20-100$ & 16 & 85 \\
\hline Pham TN & USA & $34(+29)$ & $1-97$ & 22 & -- \\
\hline Cameron DR & Australia & 30 & $25-98$ & 24 & $8(18 \%)$ \\
\hline Tasti E & Greece & 41.6 & $15-100$ & 59 & 40 \\
\hline Garcia SV & Spain & -- & $1-99$ & 40 & $20(29.8 \%)$ \\
\hline Plamu R & Finland & 24 & -- & -- & $17.4 \%$ \\
\hline
\end{tabular}

†TBSA: Total Body Surface Area. 
J. Dhaka National Med. Coll. Hos. 2011; 18 (01): 49-57

Table: 3 Psychiatric histories among the patients

\begin{tabular}{|c|c|c|c|c|c|c|c|c|c|c|}
\hline $\begin{array}{l}\text { Author \& } \\
\text { Country }\end{array}$ & & $\begin{array}{l}\text { Daniels } \\
\text { SM, USA }\end{array}$ & $\begin{array}{l}\text { Erzurum } \\
\text { VZ, } \\
\text { USA }\end{array}$ & $\begin{array}{l}\text { Wallace KL, } \\
\text { Australia }\end{array}$ & $\begin{array}{l}\text { Rastegar } \\
\text { LA, } \\
\text { Iran }\end{array}$ & $\begin{array}{l}\text { Pham } \\
\text { TN, } \\
\text { USA }\end{array}$ & $\begin{array}{l}\text { Cameron DR, } \\
\text { Australia }\end{array}$ & $\begin{array}{l}\text { Tasti E, } \\
\text { Greece }\end{array}$ & $\begin{array}{l}\text { Garcia } \\
\text { SV, } \\
\text { Spain }\end{array}$ & $\begin{array}{l}\text { Plamu R, } \\
\text { Finland }\end{array}$ \\
\hline \multirow{5}{*}{ 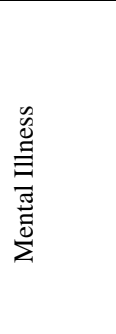 } & Schizophrenia & 5 & $\begin{array}{c}3 \\
(27.2 \%)\end{array}$ & $18 \%$ & - & $\begin{array}{c}7 \\
(6 \%)\end{array}$ & $\begin{array}{c}7 \\
(16 \%)\end{array}$ & $\begin{array}{c}7 \\
(30.3 \%)\end{array}$ & $73.8 \%$ & 8 \\
\hline & Depression & 2 & $\begin{array}{c}6 \\
(54.5 \%)\end{array}$ & $17 \%$ & $\begin{array}{c}21 \\
(47.7 \%)\end{array}$ & $\begin{array}{c}20 \\
(41 \%)\end{array}$ & $\begin{array}{c}7 \\
(16 \%)\end{array}$ & $\begin{array}{c}13 \\
(53.5 \%)\end{array}$ & - & 10 \\
\hline & Bipolar Disorder & 1 & - & $2 \%$ & - & $22 \%$ & - & - & - & - \\
\hline & Psychosis & 1 & - & - & $\begin{array}{c}4 \\
(9.1 \%)\end{array}$ & - & - & $\begin{array}{c}1 \\
(4.3 \%)\end{array}$ & - & - \\
\hline & Personality Disorder & - & 1 & $17 \%$ & $\begin{array}{c}7 \\
(15.9 \%)\end{array}$ & $31 \%$ & $\begin{array}{c}17 \\
(39 \%)\end{array}$ & $\begin{array}{c}2 \\
(8.6 \%)\end{array}$ & - & - \\
\hline \multirow{7}{*}{ 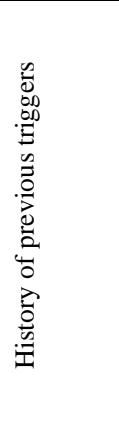 } & Suicide attempt & 7 & $\begin{array}{c}7 \\
(63.6 \%)\end{array}$ & $15 \%$ & - & $\begin{array}{c}15 \\
(47 \%)\end{array}$ & $\begin{array}{c}20 \\
(45 \%)\end{array}$ & $\begin{array}{c}4 \\
(17.4 \%)\end{array}$ & $20.9 \%$ & 23 \\
\hline & $\begin{array}{l}\text { Previous Psyc. Hosp } \\
\text { admission }\end{array}$ & $53 \%$ & - & - & - & - & - & - & - & - \\
\hline & Sexual abuse & 5 & - & - & 1 & - & - & - & - & - \\
\hline & $\begin{array}{l}\text { Substance/Alcohol } \\
\text { abuse }\end{array}$ & - & 2 & - & - & $41 \%$ & 13 & - & $9.4 \%$ & - \\
\hline & $\begin{array}{l}\text { Past psychiatric } \\
\text { problem }\end{array}$ & 9 & $\begin{array}{c}10 \\
(90.9 \%)\end{array}$ & $69 \%$ & $\begin{array}{c}48 \\
(43.6 \%)\end{array}$ & $\begin{array}{c}29 \\
(91 \%)\end{array}$ & - & $\begin{array}{c}23 \\
(43.3 \%)\end{array}$ & $60.3 \%$ & - \\
\hline & Arson/PTSD $\dagger$ & - & 1 & - & $\begin{array}{c}4 \\
(9.1 \%)\end{array}$ & - & - & - & - & - \\
\hline & Others & - & - & - & 35 & - & - & - & - & - \\
\hline
\end{tabular}


J. Dhaka National Med. Coll. Hos. 2011; 18 (01): 49-57

Appendices:

(a) List of the studies used for review.

\begin{tabular}{ll}
\hline $\begin{array}{l}\text { Number of } \\
\text { the Study }\end{array}$ & \multicolumn{1}{c}{ Reference Information } \\
\hline Study-1 & $\begin{array}{l}\text { Cameron DR, Pegg SP, Muller M. Self-inflicted burns. Burns 1997; 23(6): } \\
519-21 .\end{array}$
\end{tabular}

Study-2 Daniels SM, Fenley JD, Powers PS, Cruse CW. Self-inflicted burns: a tenyear retrospective study. J Burn Care Rehabil 1991; 12(2):144-7.

Study-3 Erzurum VZ and Varcellotti J. Self-inflicted burn injuries. J Burn Care Rehabil 1999; 20: 22-4.

Study-4 Garcia-Sanchez V, Palao R, Legarre F. Self-inflicted burns. Burns 1994; 20(6): 537-8.

Study-5 Palmu R, Isometsa E, Suominen K, Vuola J, Leppavuori A, Lonnqvist J. Self-inflicted burns: an eight year retrospective study in Finland. Burns 2004; 30(5): 443-7.

Study-6 Pham TN, King JR, Palmieri TL, Greenhalgh DG. Predisposing factors for self-inflicted burns. J Burn Care Rehabil 2003; 24(4): 223-7.

Study-7 Rastegar LA and Alaghehbandan R. Epidemiological study of self-inflicted burns in Tehran, Iran. J Burn Care Rehabil 2003, 24(1), 15-20.

Study-8 Tsati E, Iconomou T, Tzivaridou D, Keramidas E, Papadopoulos S, Tsoutsos D. Self-inflicted burns in Athens, Greece: a six-year retrospective study. J Burn Care Rehabil 2005; 26(1): 75-8.

Study-9 Wallace LK and Pegg SP. Self-inflicted burn injuries: an 11-year retrospective study. J Burn Care Rehabil 1999; 3(4): 191-4. 


\section{References}

1. Satcher D. Mental health: A report of the Surgeon General executive summary. Professional Psychology: Research and Practice 2000; 31: 5-13.

2. World Health Organization (WHO). Report of the International Pilot Study of Schizophrenia. Geneva: WHO; 1973. Volume 1.

3. World Health Organization (WHO). Schizophrenia: an international follow-up study. New York: JohnWiley; 1979.

4. Jablensky A, Sartorius N, Ernberg G, Anker M, Korten A, Cooper JE, et al. Schizophrenia: manifestations, incidence and course in different cultures. A World Health Organization tencountry study. Psychol Med Monogr Suppl 1992; 20: 1-97.

5. Murray CJL and Lopez AD, editors. Summary: The global burden of disease: a comprehensive assessment of mortality and disability from diseases, injuries, and risk factors in 1990 and projected to 2020. Cambridge (MA): Published by the Harvard School of Public Health on behalf of the World Health Organization and the World Bank, Harvard University Press, 1996.

6. Fenton WS, McGlashan TH, Victor BJ, Blyler CR. Symptoms, subtype, and suicidality in patients with schizophrenia spectrum disorders. Am J Psychiatry 1997; 154: 199-204.

7. Steadman HJ, Mulvey EP, Monahan J, Robbins PC, Appelbaum PS, Grisso T, et al. Violence by people discharged from acute psychiatric inpatient facilities and by others in the same neighborhoods. Arch of Gen Psychiatry 1998; 55: 393 401.

8. Swartz MS, Swanson JW, Hiday VA, Borum R, Wagner R, Burns BJ. Taking the wrong drugs: the role of substance abuse and medication noncompliance in violence among severely mentally ill individuals. Social Psychiatry and Psychiatric Epidemiology 1998; 33: S75-S80.

9. Murphy SL. Deaths: final data for 1998. Natl Vital Stat Rep. 2000. 24;48(11):1-105.

10. Satcher D. The Surgeon General's Call to Action to Prevent Suicide 1999. Department of

Health and Human Services. U.S. Public Health Service. Washington, DC. 1999.

11. Krummen DM, James K, Klein RL. Suicide by burning: A retrospective review of the Akron Regional Burn Center. Burns 1998; 24: 147-9.
12. Mabrouk AR, Omar ANM, Massoud K, Sherif MM, Sayed NE. Suicide by burns: A tragic end. Burns 1999; 25: 337-339.

13. Erzurum VZ, Varcellotti J. Self-inflicted burn injuries. J Burn Care Rehabil 1999; 20: 22-24.

14. Wallace LK, Pegg SP. Self-inflicted burn injuries: an 11year retrospective study. J Burn Care Rehabil 1999; 3: 191-4.

15. Bille-Brahe U, Jessen G. Suicide in Denmark, 1922-1991: the choice of method. Acta Psychiatr Scand. 1994; 90:91-6.

16. Wagle SA, Wagle AC, Apte JS. Patients with suicidal burns and accidental burns: A comparative study of sociodemographic profile in India. Burns 1999; 25: 158-61.

17. Sheth H, Dziewulski P, Settle AD. Self-inflicted burns: A common way of suicide in the Asian population. A ten-year retrospective study. Burns 1994; 20: 334-5.

18. Daniels SM, Fenley JD, Powers PS, Cruse CW. Selfinflicted burns: a ten-year retrospective study. J Burn Care Rehabil 1991; 12: 144-147.

19. Squyres V, Law EJ, Still JM. Self-inflicted burns. J Burn Care Rehabil 1993; 14: 476-479.

20. Cameron DR, Pegg SP, Muller M. Self-inflicted burns. Burns 1997; 23: 519-521.

21. Davidson TI, Brown LC. Self-inflicted burns: A five-year retrospective study. Burns 1985; 11: 157-60.

22. Klasen HJ, Van-der-Tempel GL, Hekert J, Saur HC. Attempted suicide by means of burns. Burns 1989; 15: 88-92.

23. Hammond JS, Ward CG, Pereira E. Self-inflicted burns. J Burn Care Rehabil 1988; 9:178-9.

24. Berry CC, Patterson TL, Wachtel TL, Frank HA. Behavioral factors in burn mortality and length of stay in hospital. Burns Incl Therm Inj 1984; 10:409-14

25. Rastegar LA, Alaghehbandan R. Epidemiological study of self-inflicted burns in Tehran, Iran. J Burn Care Rehabil 2003; 24: $15-20$.

26. Pham TN, King JR, Palmieri TL, Greenhalgh DG. Predisposing factors for self-inflicted burns. J Burn Care Rehabil 2003; 24: 223-7.

27. Garcia-Sanchez V, Palao R, Legarre F. Self-inflicted burns. Burns 1994; 20: 537-8.

28. Jacobson R, Jackson M, Berelowitz M. Self-incineration: a controlled comparison of in- patient suicide attempts, clinical 
J. Dhaka National Med. Coll. Hos. 2011; 18 (01): 49-57 features and history of self-harm. Psychological Medicine 1989; 16: 107-16.

29. Tsati E, Iconomou T, Tzivaridou D, Keramidas E, Papadopoulos S, Tsoutsos D. Self-inflicted burns in Athens, Greece: a six-year retrospective study. J Burn Care Rehabil 2005; 26: 75-8.

30. Palmu R, Isometsa E, Suominen K, Vuola J, Leppavuori A, Lonnqvist J. Self-inflicted burns: an eight year retrospective study in Finland. Burns 2004: 30: 443-447.

31. Bhaduri R. Self-inflicted burns. Burns 1982; 8: 403-407.

32. BenMeir P, Sagi A, BenYakar Y, Rosenberg L. Suicide attempts by self-immolation - our experience. Burns 1990; 16: 257-8.

33. Andreasen NC, Noyes R. Suicide attempted by selfimmolation. American J Psychiatry 1975, 132,554-556. 